\title{
A Sustentabilidade do endividamento externo brasileiro no período 1963-72: uma análise empírica
}

\author{
Eduardo F. Bastian \\ Professor - Instituto de Economia - Universidade Federal do Rio de Janeiro (IE-UFRJ) \\ Endereço: Av. Pasteur, 250 - sala 103, Urca - Rio de Janeiro/RJ \\ CEP: 22290-240 - E-mail: eduardobastian@ie.ufrj.br
}

Recebido: 09/10/2015. Aceite: 20/02/2017.

\begin{abstract}
Resumo
O presente artigo analisa o grau de vulnerabilidade externa da economia brasileira no início do governo presidencialista de João Goulart (1963-64). Para tanto, utiliza-se de um modelo simples que permite avaliar o grau de solvência externa de um país ao longo do tempo a partir de projeções para o indicador passivo externo líquido sobre exportações de bens e serviços. As projeções para o período 1963-72 sinalizam que o país estava em uma situação de vulnerabilidade externa naquele momento, mas que esta condição poderia ser contornada através de uma taxa adequada de crescimento das exportações de bens e serviços. Estas projeções são contrastadas com o comportamento efetivo da economia brasileira no período 1963-72. Os resultados mostram que o forte crescimento das exportações de bens e serviços neste período reduziu o grau de vulnerabilidade externa do país, mas que, ainda assim, este processo de ajustamento externo entre 1963-72 deve ser relativizado.
\end{abstract}

\section{Palavras-Chave}

Passivo externo líquido. Exportações. Vulnerabilidade externa.

\begin{abstract}
This article analyzes Brazil's external vulnerability at the beginning of João Goulart's presidentialist term (1963-64). Based on projections for the indicator net external liabilities as a share of the exports of goods and services for the period 1963-72, it shows that Brazil was externally vulnerable in 1963 , but this situation could be reverted in case of a sufficiently high exports' growth rate. The projections were then contrasted with the actual data of the period 1963-72. Data showed that Brazil's external vulnerability was reduced thanks to exports growth, but also dispute the idea that there was an actual external adjustment process in the period.
\end{abstract}

\section{Keywords}

Net external liabilities. Exports. External vulnerability.

\section{JEL Classification}

N16. F32. F34.

- O autor agradece aos pareceristas anônimos pelas sugestões que certamente aperfeiçoaram o artigo e aos participantes do I Congresso Fluminense de História Econômica em Niterói (RJ) e do X Congresso Brasileiro de História Econômica e XI Conferência Internacional de História de Empresas em Juiz de Fora (MG) por seus comentários e sugestões a versões anteriores desse artigo. O autor agradece ainda a Marta Castilho pela sugestão de uso dos dados do Comtrade, a Francisco Eduardo Pires de Souza e Carlos Pinkusfeld Bastos pelas informações referentes às mudanças de 2015 na metodologia do Balanço de Pagamentos e a Franklin Serrano pelas conversas sobre indicadores de vulnerabilidade externa. Os eventuais erros e omissões remanescentes são de minha responsabilidade. 


\section{Introdução}

O problema da vulnerabilidade externa é um tema que frequentemente preocupou os economistas brasileiros ao longo do século XX e início do século XXI. Neste período houve, de fato, inúmeros episódios de crises de balanço de pagamentos, sendo os mais recentes a crise da dívida externa dos anos 1980 e a crise cambial de 1998-1999. Nos últimos dez anos, o cenário externo foi mais favorável e não houve nenhum problema mais agudo nas contas externas. Todavia, diante dos seguidos déficits em conta corrente nos últimos anos e do déficit da balança comercial em 2014, o tema da vulnerabilidade externa retornou ao debate brasileiro.

A primeira metade da década de 1960 foi um desses momentos históricos em que as dificuldades nas contas externas se fizeram sentir. $\mathrm{Na}$ realidade, naquele período, os problemas iam além da questão externa e o Brasil encontrava-se em uma situação econômica delicada: após a fase de euforia vivida durante o governo de Juscelino Kubitschek (1956-61), a economia começava a sofrer com um quadro de aceleração da inflação e taxas de crescimento cadentes. Ao mesmo tempo, o contexto político era também conturbado e, entre 1961 e 1963, o regime político foi modificado duas vezes. Foi nesse contexto turbulento que o Plano Trienal foi formulado no último trimestre de 1962 para ser o plano econômico de João Goulart para o triênio 1963-65 caso a opção pelo presidencialismo saísse vitoriosa - como acabou ocorrendo - no plebiscito de janeiro de $1963 .{ }^{l}$ O Trienal tinha por objetivo controlar a inflação e retomar o processo de crescimento econômico. No entanto, para atingir este duplo propósito, era preciso enfrentar muitos desafios, dentre os quais um dos mais prementes, que era o de lidar com os problemas de balanço de pagamentos a que o país estava sujeito à época. Segundo a visão exposta no plano, haveria, para o período 1963-65, pagamentos externos vultosos - sob a forma de amortizações e juros - além da previsão de déficits em conta corrente e no balanço de pagamentos. No caso, os dados apresentados no Trienal previam pagamentos ao exterior no triênio 1963-65 da ordem de US\$ 1,66 bilhão, e estimava déficits em transações correntes que, na soma do referido triênio, chegariam a US\$ 545 milhões (PLANO TRIENAL, 1962:21-22). Neste contexto, os formuladores do Trienal apontavam, inclusive, para a urgência de obter acordos de refinanciamento da dívida externa.

1 O plebiscito de janeiro de 1963 decidiria se o país voltaria ao regime presidencialista ou continuaria no regime parlamentarista, solução adotada no segundo semestre de 1961 para contornar a crise política instaurada após a renúncia repentina de Jânio Quadros. 
O presente artigo tem por objetivo avaliar qual era o grau de vulnerabilidade externa a que estava exposta a economia brasileira no começo do ano de 1963, ou seja, precisamente no início do mandato presidencialista de João Goulart. Para tanto, utiliza-se um modelo simples inicialmente formulado por Mário Henrique Simonsen em fins dos anos 1970 e posteriormente refinado pelo próprio Simonsen e por Rubens Penha Cysne, o qual permite avaliar o grau de solvência externa de um país ao longo do tempo a partir de projeções para o indicador passivo externo líquido sobre exportações de bens e serviços. Em particular, pretendese aqui avaliar o grau de solvência externa da economia brasileira em 1963 a partir de projeções desse indicador para o período 1963-72. Modelos deste tipo e exercícios de avaliação de sustentabilidade do endividamento externo foram muito populares durante a crise da dívida nos 1980 e, posteriormente, durante outras fases em que a economia esteve mais exposta a crises de balanço de pagamentos, como foi o caso da segunda metade dos anos 1990 e começo dos anos 2000. ${ }^{2}$ Todavia, exercícios desta natureza ainda são escassos para períodos históricos anteriores à segunda metade da década de 1970. Assim, ao fornecer uma medida quantitativa de solvência externa do Brasil em 1963, o presente trabalho pode contribuir para uma melhor compreensão do grau de vulnerabilidade externa a que estava sujeita a economia brasileira naquele período.

Após calcular a trajetória prevista do indicador passivo externo líquido sobre exportações de bens e serviços para o período 1963-72, o artigo compara a trajetória estimada do indicador de solvência externa para o período 1963-72 - a partir dos parâmetros do final de 1962 - com o comportamento efetivamente descrito por esse indicador no período 1963-72. No caso, o objetivo é analisar como as políticas implantadas no período contribuíram para melhorar (ou piorar) a solvência externa da economia brasileira em relação ao que seria esperado a partir dos parâmetros de 1962. Nesse contexto, haverá uma análise das políticas implantadas durante o governo presidencialista de João Goulart (19634) e, especialmente, das políticas adotadas durante os três primeiros governos da ditadura militar.

O artigo está dividido em duas seções, além desta introdução e das conclusões. A segunda é dedicada à apresentação do modelo de Simonsen e Cysne e aos cálculos. No caso, projeta-se o comportamento do indicador

2 Para exemplos de trabalhos que procuraram medir o grau de vulnerabilidade externa da economia brasileira nos anos 1990 e 2000, ver Carneiro (1997), Giambiagi et al. (1998) e Pires de Souza (2002). 
passivo externo líquido sobre exportações de bens e serviços no período 1963-72, a partir das condições vigentes ao final de 1962. Além disso, caso a projeção indique um comportamento explosivo do endividamento externo brasileiro para o período em questão, calcula-se a taxa de crescimento das exportações que seria requerida para estabilizar o grau de endividamento. A terceira seção, por sua vez, discute os resultados obtidos na seção anterior, comparando estes resultados das estimações com o comportamento efetivo das variáveis no período 1963-72 e analisando as razões que explicam as eventuais discrepâncias.

\section{A sustentabilidade do endividamento externo brasileiro (1963-72)}

O grau de vulnerabilidade externa de um país pode ser avaliado a partir de um exercício simples, bastante utilizado no Brasil durante a crise da dívida externa nos anos 1980. Trata-se de um exercício baseado em um modelo proposto por Mário Henrique Simonsen e Rubens Penha Cysne, modelo este que foi inteiramente construído a partir de relações básicas da Contabilidade Social, não estando atrelado, portanto, a hipóteses teóricas específicas ou a aspectos singulares do Brasil. Esta característica faz com que este modelo possa ser replicado em outros contextos históricos e para o caso de outros países. Noutros termos, trata-se de um modelo útil para analisar o problema da vulnerabilidade externa no Brasil não apenas no passado, mas também hoje em dia no presente, sendo que a sua aplicação não se restringe ao caso brasileiro, podendo, por exemplo, ser utilizado também para avaliar o caso dos países europeus que hoje enfrentam dificuldades nas contas externas.

No caso, a intenção do modelo é observar como evolui no tempo a capacidade de um país de honrar as suas dívidas caso sejam mantidas as condições econômicas vigentes em um determinado ano arbitrariamente escolhido. Noutros termos, pensando no caso brasileiro quando do começo do governo presidencialista de João Goulart, o exercício permite observar como evoluiria no tempo a capacidade de o Brasil honrar seus compromissos externos, mantidas as condições prevalecentes no começo do ano de 1963, momento em que se inicia a fase presidencialista do governo Goulart. 
Assim, tal como proposto por Simonsen \& Cysne (1989), o exercício está baseado na Equação 1, a qual permite avaliar o comportamento esperado do grau de solvência externa de um país a partir de determinadas condições iniciais. ${ }^{3}$

$$
\mathrm{z}_{(\mathrm{t})}=\left[\mathrm{z}_{0}-\mathrm{h} /(\mathrm{i}-\mathrm{x})\right] \mathrm{e}^{(\mathrm{i}-\mathrm{x}) \mathrm{t}}+\mathrm{h} /(\mathrm{i}-\mathrm{x})
$$

$\mathrm{z}_{0}=$ valor inicial da relação passivo externo líquido sobre exportações de bens e serviços

$\mathrm{h}=$ superávit da balança comercial sobre exportações de bens e serviços ${ }^{4}$

$\mathrm{i}=$ taxa de remuneração do passivo externo líquido

$\mathrm{x}=$ taxa instantânea de crescimento das exportações de bens e serviços

$\mathrm{t}=$ tempo

No caso, a variável $z$ resulta da razão entre o passivo externo líquido do país e suas exportações de bens e serviços. O passivo externo líquido mede o montante de passivos externos (descontados os ativos) que um país possui em determinado momento do tempo. Mais precisamente, segundo Simonsen \& Cysne (1989), o passivo externo líquido era igual a:

Saldo devedor dos empréstimos contraídos pelo país no exterior - Saldo credor dos empréstimos concedidos pelo país ao exterior + Estoque de capitais estrangeiros de risco investidos no país Estoque de capitais nacionais de risco investidos no exterior + Saldo das obrigações a curto prazo do país com o exterior - Saldo das reservas internacionais - Saldo das reservas bancárias no exterior (SIMONSEN; CYSNE, 1989:71).

3 Para o desenvolvimento do modelo que leva até a Equação 1, ver o apêndice.

4 Na versão original de Simonsen \& Cysne (1989), o parâmetro $h$ designava a transferência líquida de recursos sobre as exportações de bens e serviços. Ocorre que, após mudanças metodológicas no balanço de pagamentos, a balança comercial passou a incorporar - além das exportações e importações de bens - as exportações e importações de serviços. Assim, o que antes era chamado de transferência líquida de recursos hoje equivale a um superávit na balança comercial, e o que era chamado de hiato de recursos hoje corresponde a um déficit na balança comercial. Para uma apresentação sintética da estrutura do balanço de pagamentos, ver Terra (2014). 
A variável $z$ (passivo externo líquido sobre exportações de bens e serviços) fornece uma medida de capacidade de pagamento de um país, uma vez que corresponde aos anos de exportação que seriam necessários para quitar todo o passivo externo líquido (GIAMBIAGI et al., 1998:448). Esta característica se deve ao fato de os países devedores não emitirem moeda internacional, de modo que as exportações são um indicador importante para os credores internacionais, uma vez que constituem a principal fonte que os devedores têm para obtenção de divisas (SIMONSEN; CYSNE, 1989:73-4).

Por fim, quanto à análise do grau de vulnerabilidade externa propriamente, Simonsen \& Cysne (1989) propuseram uma regra de bolso que permite avaliar a sustentabilidade do endividamento a partir de diferentes valores do parâmetro $z$. Quando $z<2$, diz-se que o país está em uma situação confortável, caso $z$ esteja entre 2 e 4, então a posição é duvidosa e, para $z>4$, o país está em situação crítica (SIMONSEN; CYSNE, 1989:74). Originalmente, a regra foi pensada pelos autores para a segunda metade dos anos 1970, momento em que havia um grau de liquidez considerável para economias emergentes em função dos petrodólares. Como o presente estudo foca no final dos anos 1960 e começo dos 1970, período em também havia ampla liquidez no mercado internacional para emergentes, parece razoável seguir a regra sugerida pelos autores.

Apesar de a relação passivo externo líquido sobre exportações de bens e serviços ser um indicador muito utilizado em estudos de vulnerabilidade externa, há algumas críticas a esse indicador que levam à sugestão de indicadores alternativos. No caso, a principal crítica deve-se ao fato de o conceito de passivo externo líquido incorporar diferentes tipos de passivos - como dívidas e o estoque de investimento direto estrangeiro - de maneira que utilização do valor absoluto do passivo externo líquido não leva em consideração os impactos que diferentes composições do passivo podem ter no grau de vulnerabilidade externa. Medeiros e Serrano (2001) apresentam observações interessantes no que tange a essa questão. Por um lado, destacam que diferentes componentes do passivo possuem diferentes taxas de remuneração. Por outro, chamam a atenção para o fato de que a estrutura de prazos depende também da composição do passivo externo (MEDEIROS e SERRANO, 2001:120). Por exemplo, a estrutura de prazos de investimentos estrangeiros diretos é muito distinta daquela de títulos de dívida externa em particular de curto prazo. Ademais, dívidas têm data definida de 
vencimento, enquanto investimentos apenas sinalizam uma potencial demanda futura por divisas em algum momento não definido precisamente (LARA, 2012: 20-23). Esse ponto é muito importante, pois "crises de liquidez externa e a crise cambial propriamente dita em geral ocorrem apenas quando subitamente os credores externos recusam-se a refinanciar os compromissos externos que vencem em determinado período" (MEDEIROS e SERRANO, 2001: 120). Assim, para um dado valor absoluto de passivo externo líquido, quanto menor a participação do IDE e maior a participação de dívida externa - especialmente de curto prazo - em relação ao total do passivo externo, mais exposto o país está a uma crise cambial ou de liquidez em função de uma reversão nos fluxos de capitais (MEDEIROS e SERRANO, 2001: 121; LARA, 2012: 21). ${ }^{5}$

Diante dessas questões, Medeiros e Serrano (2001) recomendam a utilização de indicadores alternativos. Dada a dificuldade prática de distinguir as diferentes taxas de retorno dos diversos componentes do passivo externo, os autores recomendam analisar a razão déficit em conta corrente/exportações como indicador da sustentabilidade de uma trajetória de endividamento externo. ${ }^{6}$ Ademais, como entendem que o risco de crise cambial (ou crise de liquidez externa) depende do montante dos passivos que está para vencer e da capacidade de o país honrar esses compromissos de curto prazo, recomendam a utilização da razão entre passivos externos de curto prazo e reservas cambiais como indicador de fragilidade financeira externa (MEDEIROS e SERRANO, 2001: 120-1). Nesse tocante, Lara (2012) esclarece que é preciso distinguir liquidez externa de solvência externa. O conceito de solvência diz respeito à questão da sustentabilidade do endividamento e está atrelada à capacidade exportadora do país, de modo que pode ser medida por indicadores como passivo externo líquido sobre exportações de bens e serviços - como em Simonsen e Cysne (1989) - ou pela razão déficit em conta corrente sobre exportações - como sugerem Medeiros e Serrano (2001). Por sua vez, o conceito de liquidez externa está ligado à probabilidade de crises cambiais e deve ser avaliado a partir das reservas internacionais acumuladas, uma vez que elas medem a capacidade de o

5 Um outro aspecto que aponta para a importância de levar em consideração a estrutura do passivo externo está relacionado ao risco cambial. Conforme explica Lara (2012), no caso de investimentos em portfólio, o risco cambial é do agente externo, enquanto, no caso de dívidas, o risco cambial é do tomador (Lara, 2012: 23).

6 Conforme explica Lara, a razão entre déficit em conta corrente sobre exportações permite avaliar a tendência da razão passivo externo líquido sobre exportações de bens e serviços. Assim, "quanto maior for a razão déficit em conta-corrente sobre exportações, maior será o crescimento do passivo externo como proporção das exportações" (Lara, 2014: 22). 
país fazer frente a uma súbita demanda por moeda estrangeira. Nesse contexto, o indicador mais recomendável seria a razão entre passivos externos de curto prazo e reservas cambiais (LARA, 2012: 20-1).

Apesar do mérito das observações desses autores, optou-se aqui por seguir a abordagem original de Simonsen e Cysne (1989), o que, na prática, significa centrar a discussão na análise da solvência externa e, ademais, utilizar o passivo externo líquido sobre exportações de bens e serviços como referência principal para analisar a questão. Como o presente artigo baseia-se em um modelo proposto por Simonsen e Cysne (1989), pareceu mais razoável seguir na íntegra a abordagem desses autores. De todo modo, na parte empírica do artigo sobre o caso brasileiro entre 1962-72, far-se-ão algumas observações em relação aos indicadores déficit em conta corrente sobre exportações e razão entre passivos externos de curto prazo e reservas cambiais. Além disso, como foi observado acima que a composição do passivo externo líquido entre dívida externa líquida e estoque de IDE é algo que pode ser importante, será apresentada também a variação do indicador dívida externa líquida sobre exportações de bens e serviços entre 1962 e 1972. A inclusão desses outros indicadores fornecerá uma perspectiva mais ampla sobre a sustentabilidade do endividamento externo brasileiro naquele momento do que se a análise ficasse restrita apenas ao indicador passivo externo líquido sobre exportações de bens e serviços.

Retornando à Equação 1 proposta por Simonsen e Cysne (1989), a equação em questão permite, portanto, avaliar o comportamento esperado do grau de solvência externa de um país a partir de determinadas condições iniciais. Naturalmente, a limitação deste tipo de abordagem reside no fato de os valores dos parâmetros se manterem constantes ao longo do tempo. Assim, os resultados que o modelo fornece refletem o que irá ocorrer no futuro caso os valores escolhidos para os parâmetros no ano base não sofram alterações, de modo que as trajetórias obtidas são sempre uma extrapolação das condições iniciais. Todavia, esta limitação não elimina o interesse no uso deste instrumental. A verificação de que um país se encontra em uma trajetória perigosa a partir de determinadas condições iniciais significa, efetivamente, que este país se encontra em uma situação vulnerável e que deve, portanto, tomar já no curto prazo medidas para reverter o quadro. 
O exercício aqui proposto consite justamente em utilizar a Equação 1 para descrever a trajetória da capacidade de pagamento dos compromissos externos do Brasil se fossem mantidas as condições prevalecentes quando o Plano Trienal foi colocado em prática, ou seja, no primeiro trimestre de 1963. Com isso, ter-se-á uma medida do grau de vulnerabilidade externa a que estava exposta a economia brasileira quando Goulart iniciou o seu mandato presidencialista.

Para viabilizar a realização deste exercício, é preciso obter os parâmetros que descrevem as condições iniciais, o que, no caso, significa tomar os dados referentes ao fechamento do ano de 1962. Alguns dos parâmetros são simples de calcular, como a taxa instântenea de crescimento das exportações de bens e serviços, a qual consiste simplesmente na taxa de crescimento destas exportações entre 1961 e 1962. Outros requerem um esforço maior. Como não há dados do passivo externo líquido em 1962 e as estatísticas disponíveis não permitem o cálculo exato, utilizou-se como proxy o valor da dívida externa líquida de $1956^{7}$ adicionado pelos resultados da conta corrente entre 1957 e 1962, dado que, segundo Simonsen e Cysne (1989), estes valores da conta corrente fornecem aproximadamente a variação do passivo externo líquido ao longo do tempo (SIMONSEN; CYSNE, 1989:71). Desta forma, o valor aproximado do passivo externo líquido do Brasil em 1962 era de US\$ 4,271 bilhões. Como o valor das exportações de bens e serviços de 1962 foi de aproximadamente US $\$ 1,292$ bilhão, logo o valor de $z_{0}$ foi de 3,304 . Por outro lado, como houve um déficit na balança comercial de quase US\$ 293 milhões, a fração das exportações transferida para o exterior (h) em 1962 foi igual a $-0,227 .^{8}$

7 O ano de 1956 foi tomado como ponto de partida, pois é o primeiro ano para o qual há estatísticas da dívida externa bruta no Banco Central do Brasil. O valor da dívida externa líquida para este ano (US\$ 2,128 bilhões) resultou da subtração da dívida externa bruta (US \$2,736 bilhões) pelo montante de reservas internacionais (liquidez internacional) da ordem de US\$ 608 milhões. Os dados da dívida externa foram obtidos no Ipeadata e corresponde à dívida externa total, incluindo empréstimos intercompanhia. Os dados das reservas internacionais foram obtidos no Banco Central.

8 Todos os dados utilizados neste estudo são referentes à metodologia do balanço de pagamentos vigente no Brasil até o primeiro semestre de 2015. Em 2015, foi introduzida uma nova metodologia. Entre outras coisas, a nova metodologia modificou a forma de inclusão dos lucros reinvestidos e juros reinvestidos. Ademais, a conta financeira passou a ter sinal positivo para a saída de capitais e negativo para entrada de capitais. Por fim, as reservas internacionais passaram a entrar na conta financeira e com sinal positivo - para o caso de aumento de reservas. Para maiores detalhes, ver: http://www.bcb.gov.br/pt-br/\#!/n/6MANBALPGTO. Acessado em 21 de dezembro de 2016. 
O cálculo da taxa de remuneração do passivo externo líquido (i) para 1962 requer, por sua vez, levar em consideração os juros que remuneram a dívida externa líquida e os lucros e dividendos associados ao estoque de investimento externo direto e dos investimentos de portfólio. No caso, o cálculo se dá a partir dos juros e lucros e dividendos de 1962 e da dívida externa líquida e do estoque de investimento externo direto e dos investimentos de portfólio de 1961. Para simplificar, consideraremos que a parcela lucros e dividendos em 1962 foi igual a zero, ${ }^{9}$ de modo que a taxa de remuneração do passivo externo líquido é igual à taxa de juros que remunera a dívida externa líquida. Assim, a taxa de remuneração do passivo externo líquido (i) para 1962 é calculada a partir da divisão dos gastos com juros em 1962 - iguais a US\$ 121 milhões - sobre o montante da dívida externa líquida do ano anterior (US\$ 2,821 bilhões), ${ }^{10}$ o que gera uma taxa igual a 0,043 . Os dados estão sumarizados na Tabela 1.11

Tabela 1 - Parâmetros de 1962

\begin{tabular}{llll}
\hline $\mathrm{X}=$ & 1292,885 & Div $1961=$ & 2821 \\
$\mathrm{H}=$ & $-292,915$ & $\mathrm{~J}=$ & 121 \\
$\mathrm{~h}=$ & $-0,227$ & $\mathrm{~L}+\mathrm{DIV}=$ & 0 \\
$\mathrm{X}=$ & $-0,157$ & $\mathrm{i}=$ & 0,043 \\
$\mathrm{D}=$ & 4271,310 & $(\mathrm{i}-\mathrm{X})=$ & 0,200 \\
$\mathrm{Z}_{0}=$ & 3,304 & $\mathrm{~h} /(-\mathrm{-}) \mathrm{x})$ & $-1,136$ \\
\hline
\end{tabular}

Fonte: Elaboração Própria.

9 Esta simplificação não é uma hipótese heroica, pois o valor da parcela lucros e dividendos em 1962 teve um valor baixo (US\$ 18 milhões) e foi, efetivamente, igual a zero nos anos de 1963 e 1964.

${ }^{10}$ O valor da dívida externa líquida de 1961 foi obtido a partir das estatísticas do Banco Central do Brasil para a dívida externa bruta e as reservas internacionais daquele ano.

${ }^{11}$ O valor da dívida externa líquida (Div1961) é referente ao ano de 1961, enquanto que os valores do passivo externo líquido (D), das exportações de bens e serviços (X), juros (J), lucros e dividendos (L + DIV) e superávit da balança comercial (H) são referentes ao ano de 1962. Todos estes valores estão em milhões de dólares. Os demais itens são parâmetros. 
Assim, a partir dos dados acima expostos, obtém-se a Equação 2, a qual fornece a trajetória da capacidade de pagamento da economia brasileira mantidas as condições vigentes ao final de 1962. Neste contexto, cabe lembrar que, como as variáveis $(\mathrm{i}-\mathrm{x}) \mathrm{e} \mathrm{h} /(\mathrm{i}-\mathrm{x})$ são parâmetros, os valores calculados para o final de 1962 são tratados como invariáveis ao longo do tempo no exercício proposto.

$$
\mathrm{z}_{(\mathrm{t})}=[3,304+1,136] \mathrm{e}^{0,2 \mathrm{t}}-1,136
$$

Os resultados podem ser expressos graficamente, o que tem a vantagem de fornecer uma visão mais clara sobre a trajetória resultante. Para fins analíticos, um período de dez anos (1962-72) é um horizonte razoável para avaliar as condições de solvência externa a partir dos parâmetros de 1962. Assim, a trajetória pode ser visualizada no Gráfico 1.

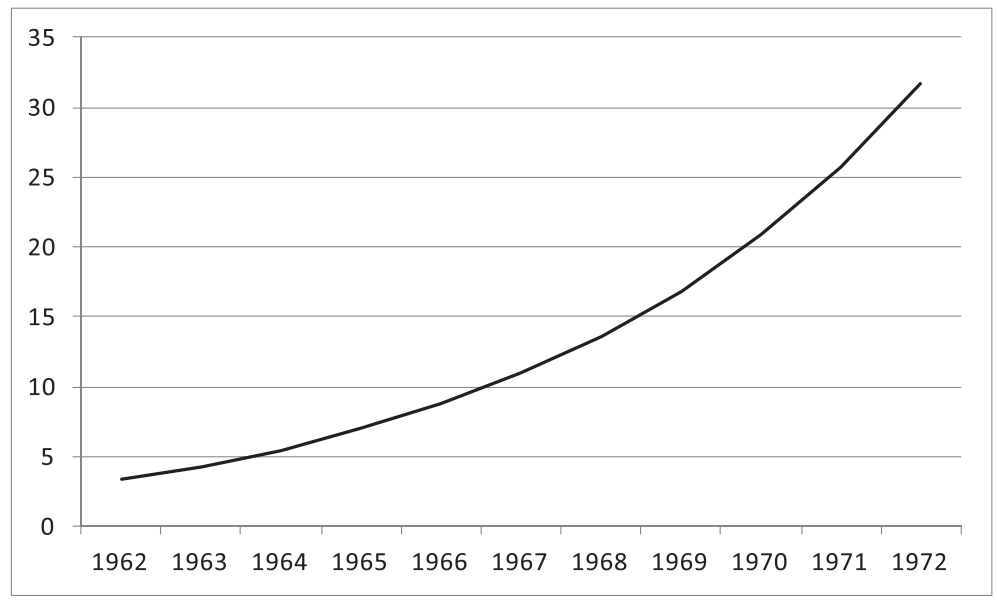

Gráfico 1 - Projeção do indicador de solvência externa brasileira (1962-72) Fonte: Elaboração própria.

O resultado mostra que o Brasil estava em uma situação extremamente vulnerável, mantidas as condições vigentes ao final de 1962. Naquele ano de 1962, o indicador $z$ era igual a 3,304, o que, pela regra de bolso proposta por Simonsen e Cysne (1989), indica que o grau de vulnerabilidade externa ainda não era insustentável, mas já estava em um patamar que levantava dúvidas acerca de sua sustentabilidade. O Gráfico 1 mostra que, mantidas as condições vigentes ao final de 1962, o en- 
dividamento externo brasileiro caminharia de forma rápida para uma situação insustentável nos dez anos que se seguiriam. Segundo a projeção, já em 1963 o indicador chegaria a 4,287, ultrapassando o nível limite de 4. Este quadro pioraria vertiginosamente, de modo que em 1966 o indicador já estaria acima de 8 e, em 1972, alcançaria o astronômico valor de 31,671. Diante desta deterioração do quadro externo, seria impossível que o país retomasse o crescimento econômico e/ou estabilizasse os preços. Assim, modificar os indicadores externos era uma questão urgente no contexto de 1963.

Todavia, apesar do caráter crítico da vulnerabilidade externa brasileira mostrado no exercício anterior, há outro exercício interessante que permite qualificar este resultado. Este exercício consiste em calcular os requisitos necessários para que, no espaço de dez anos a partir de 1963, a economia brasileira atingisse um patamar confiável no que tange à sua solvência externa. Noutros termos, a ideia é obter os valores dos parâmetros que seriam necessários para o indicador $z$ ser igual a 2. Em particular, a proposta é calcular qual seria a taxa de crescimento das exportações que seria necessária para que, no ano de 1972, o indicador $z$ fosse igual a 2, ou seja, estivesse no limite da sustentabilidade.

Supondo que $(i-x) t=y$, pode-se armar o problema da seguinte forma:

$$
\mathrm{z}_{(\mathrm{t})}=[3,304+1,136] \mathrm{e}^{\mathrm{y}}-1,136
$$

Para $t=10$, pretende-se que $z_{(t=10)}$ seja igual a 2 .

$$
\begin{gathered}
2=[3,304+1,136] e^{y}-1,136 \\
3,136=[3,304+1,136] e^{y} \\
e^{y}=0,7063 \\
y=-0,3477
\end{gathered}
$$

Como y é igual - 0,3477, então, para obter o valor de $\mathrm{x}$, tem-se que igualar este valor a (i-x)t. Como o tempo ( $\mathrm{t}$ ) é dez anos e $i$ é igual 0,043, o valor da taxa de crescimento das exportações pode ser facilmente obtido. 


$$
\begin{gathered}
(0,43-10 x)=-0,3477 \\
10 x=0,777 \\
x=0,078
\end{gathered}
$$

Dessa forma, a taxa de crescimento das exportações de bens e serviços que garantiria a sustentabilidade do endividamento externo brasileiro no período $1963-72$ seria igual a $7,8 \%$.

\section{As consequências da vulnerabilidade externa: uma discussão sobre o período 1963-72}

Os exercícios apresentados na seção anterior mostraram que a situação de solvência externa do Brasil em 1962 ainda não era insustentável, mas, mantidas as condições do final de 1962, o endividamento externo explodiria no período 1963-72. Nesse contexto, a utilização dos indicadores de solvência externa e liquidez externa sugeridos por Medeiros e Serrano (2001) e Lara (2012) ajudam a fornecer um quadro mais completo do grau de vulnerabilidade externa do Brasil no começo do governo presidencialista de João Goulart.

Do ponto de vista da liquidez externa, a sugestão desses autores era utilizar a razão entre passivos externos de curto prazo e reservas cambiais. No caso do Brasil do começo de 1963, esse indicador pode ser obtido a partir dos pagamentos internacionais de curto prazo - sob a forma de juros e amortizações - que o país tinha que fazer em 1963 e nos anos seguintes em relação ao montante de reservas internacionais que o país possuía ao final de 1962. Segundo dados do Plano Trienal, o Brasil tinha que fazer pagamentos da ordem de US\$ 591 milhões em 1963 e de US\$1,66 bilhão no acumulado do triênio 1963-65 (PLANO TRIENAL, 1962: 21-22). Como as reservas internacionais (liquidez internacional) ao final de 1962 montavam US\$ 285 milhões, as condições de liquidez externa do Brasil no começo do governo presidencialista de Goulart eram preocupantes: os passivos de curto prazo de 1963 eram mais do que o dobro das reservas internacionais, sendo que o montante de passivos de curto prazo para o triênio $1963-65$ equivalia a 5,83 vezes o montante de reservas internacionais que o país tinha no final de 1962. 
O quadro também não era benigno do ponto de vista do indicador de solvência externa sugerido por esses autores, ou seja, a razão déficit em conta corrente sobre exportações. No caso, o Brasil registrou um déficit em conta corrente em 1962 da ordem de US\$ 452 milhões, o que, diante de exportações (de bens e serviços) de US\$ 1,292 bilhão, resultava em um valor para o indicador de $-0,35$. A combinação dos resultados dos dois indicadores de solvência externa - passivo externo líquido sobre exportações de bens e serviços e déficit em conta corrente sobre exportações (de bens e serviços) - apontava para um quadro também preocupante no começo de 1963. Por um lado, o primeiro indicador mostrava uma situação de risco (parâmetro $z$ em torno de 3,3 ) e insustentabilidade no médio prazo. Por outro, o segundo indicava uma tendência de agravamento do quadro, dado que o país registrou um déficit em conta corrente em 1962.

Em síntese, havia no começo do governo presidencialista de João Goulart um quadro de estrangulamento externo, visível tanto do ponto de vista da liquidez externa, quanto da solvência externa. Para lidar com a questão da liquidez externa, era realmente imprescindível reescalonar a dívida no exterior para aliviar os pagamentos de curto prazo. Do ponto de vista da solvência externa, o quadro era também ruim, mas mais promissor: conforme demonstrado no exercício da seção anterior, esta situação poderia ser contornada no caso de um crescimento adequado das exportações de bens e serviços. $\mathrm{O}$ fato de o endividamento externo brasileiro ser insustentável no médio prazo - mas contornável através do estímulo às exportações - mostra que através de políticas econômicas adequadas era possível reverter a situação adversa nas contas externas.

A observação acima torna-se ainda mais interessante quando se analisam os dados referentes ao que efetivamente ocorreu entre 1962 e 1972 no que tange ao comportamento do indicador passivo externo líquido sobre exportações de bens e serviços. Conforme pode ser visto no Gráfico 2, esse indicador declinou de 3,304 em 1962 para 2,158 em 1972, um valor próximo à zona de segurança definida na regra de bolso sugerida por Simonsen e Cysne (1989). Ademais, a redução da vulnerabilidade externa é também atestada pelo indicador alternativo dívida externa líquida sobre exportações de bens e serviços (DEL/X), o qual caiu de 2,512 em 1962 para 1,656 em 1972. Esse resultado é relevante, pois - conforme visto na seção anterior - a composição do passivo externo líquido importa e, no caso, o maior problema em um eventual processo 
de aumento do passivo externo líquido sobre exportações de bens e serviços é quando esse processo é determinado por um aumento da dívida externa líquida.

Diante desta redução na vulnerabilidade externa ocorrida na prática entre 1962 e 1972, cabe agora tentar responder o que permitiu esta melhoria no quadro externo nesse período.

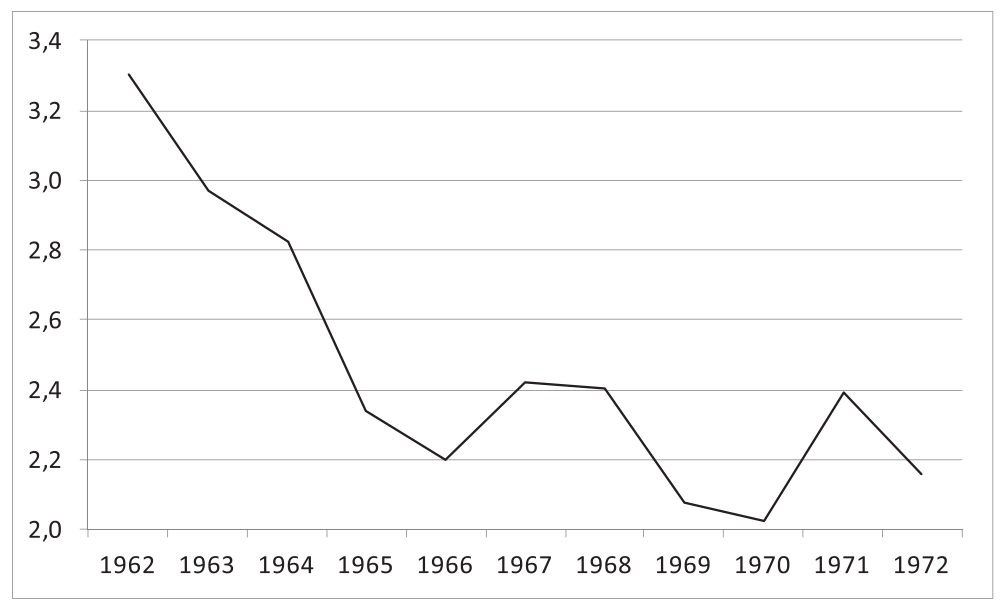

Gráfico 2 - Relação passivo externo líquido sobre exportações de bens e serviços (1962-72)

Fonte: Elaboração Própria a partir de Banco Central do Brasil e Ipeadata.

A análise do período começa com o governo João Goulart e o seu Plano Trienal. Todavia, o período presidencialista de Goulart foi muito curto, interrompido pelo golpe militar de 1964. O próprio Plano Trienal foi abandonado precocemente: o orçamento de 1964 enviado ao Congresso em 1963 ignorava as metas previstas pelo plano (FONSECA, 2004, p. 614 apud BASTIAN, 2013: 155). Na verdade, o governo Goulart acabou asfixiado pela complicada conjuntura interna e externa daquele momento. No plano interno, havia um agudo conflito distributivo, e Goulart tinha que tentar conciliar a combinação de, de um lado, o choque de custos - via medidas de inflação corretiva - e as medidas austeras do Trienal com, do outro lado, as pressões dos sindicatos, seus aliados históricos, por reajustes salariais no contexto de uma inflação que fechara 1962 na casa dos 50\% ao ano. No plano externo, a situação de estrangulamento externo descrita anteriormente tornava crucial re- 
negociar a dívida externa, mas o governo norte-americano desconfiava de Goulart e a negociação passava ainda por outras questões complexas como o pagamento de indenizações a empresas norte-americanas que tinham sido encampados em anos anteriores. A obtenção de uma ajuda externa insuficiente por parte do governo dos Estados Unidos e a dificuldade em lidar com o problema do conflito distributivo interno tornaram impossível o objetivo do Trienal de conciliar crescimento econômico com queda da inflação, o que levou não apenas ao fracasso do plano, mas também a um acirramento das tensões políticas ao longo de 1963, culminando com o golpe militar ao final do primeiro trimestre de 1964 (BASTIAN, 2013: 142; 153-65). ${ }^{12}$ Diante desse contexto, a discussão das políticas econômicas do período 1963-72 acaba centrada nas políticas dos primeiros governos da ditadura militar.

Do ponto de vista dos resultados do Gráfico 2, uma primeira hipótese explicativa que poderia ser mencionada seria uma redução no ritmo de endividamento externo no período 1962-72. No curto prazo, no começo do governo Castello Branco (1964-67), a dívida externa bruta chegou a se reduzir: segundo dados do Banco Central, houve queda de US\$ 3,61 bilhões em 1963 para 3,29 bilhões em 1964. Esta queda está provavelmente associada ao bem sucedido processo de renegociação da dívida externa promovida pelo governo militar entre 1964-65. Diferentemente do seu antecessor João Goulart, o governo Castello Branco tinha apoio do governo dos Estados Unidos e encontrou em Washington um ambiente bastante favorável à renegociação da dívida. O governo Castello Branco obteve grande ajuda externa dos Estados Unidos, bem como conseguiu reescalonar a sua dívida oficial com credores do Clube de Paris e firmar em 1965 um acordo de stand-by com o Fundo Monetário Internacional (GOULD, 2006: p. 143). ${ }^{13}$ Após 1964, a dívida externa bruta variou pouco e fechou o ano de 1967 em US\$ 3,44 bilhões, valor inferior ao de 1963.

${ }^{12}$ A estagnação da economia em 1963 aliviou o déficit em transações correntes, mas, em todo caso, não gerou um superávit. Além disso, o déficit foi financiado com perda de reservas em ouro e contratação de empréstimos - em termos desfavoráveis - com bancos privados (MALAN, 1984, p. 104 apud BASTIAN, 2013:162). Para uma análise das dificuldades econômicas enfrentadas no contexto do Plano Trienal e uma apresentação sucinta das propostas do plano para fazer frente aos problemas macroeconômicos, ver, por exemplo, Fonseca (2004), Melo et al.(2008) e Bastian (2013).

${ }^{13}$ Loureiro (2011) mostra a postura dura do governo dos Estados Unidos nas negociações com o governo Goulart. Ribeiro (2006) detalha os resultados das negociações do Brasil com os seus credores internacionais no começo da ditadura militar e o montante da ajuda recebida. A partir de documentação do Fundo Monetário Internacional, Gould (2006) mostra que a pressão dos Estados Unidos foi decisiva para que o Fundo - apesar da reticência de seu quadro técnico - firmasse um acordo de stand-by com o Brasil já no começo de 1965 (GOULD, 2006: p.137-144). 
A renegociação da dívida certamente aliviou os problemas do ponto de vista da liquidez externa. Todavia, a melhoria no indicador de solvência externa não pode ser atribuída a uma redução do endividamento externo. A partir de 1968, a dívida brasileira cresceu velozmente, chegando a US\$ 4,09 bilhões em 1968, US\$ 6,24 bilhões em 1970 e, finalmente, US\$ 11,46 bilhões em 1972. Levando em conta que a dívida externa bruta em 1962 era de US\$ 3,53 bilhões em 1962, ela quase triplicou no período 1962-72. Quanto à dívida externa líquida, o aumento foi menor em função do aumento das reservas internacionais, mas, ainda assim, foi expressivo, uma vez que aumentou de US\$ 3,248 bilhões em 1962 para US\$ 7,281 bilhões em 1972. Houve, portanto, um crescimento muito significativo no endividamento externo.

O que explica este aumento no endividamento no período? É possível sugerir três fatores. Em primeiro lugar, houve, na década de 1960, a expansão do mercado de eurodólares, o que significou um grande aumento da disponibilidade internacional de capitais para países em desenvolvimento. Segundo Bonelli \& Malan (1976), a "liquidez internacional cresceu em 4 anos (entre 1969 e 1973) a uma taxa média anual de 24\% ao ano, enquanto a média anual para os 20 anos anteriores (1949/1969) havia sido da ordem de 2,8\% ao ano" (BONELLI; MALAN, 1976: p. 359). Este movimento de maior disponibilidade de crédito externo foi acompanhado por um alargamento dos prazos e barateamento das condições para tomada de recursos. Neste contexto, o Brasil - assim como outros países em desenvolvimento - usufruiu desta conjuntura de acesso facilitado ao crédito externo (WELLS, 1973: p.17). A maior liquidez internacional somou-se às reformas financeiras feitas pelo governo brasileiro entre 1964-66 que ampliaram o grau de abertura da economia do país ao capital estrangeiro de risco e de empréstimos. Entre outras coisas, foram promulgadas leis que regulamentaram a captação direta de recursos externos por empresas privadas nacionais e, igualmente, a captação de empréstimos externos por parte de bancos nacionais com vistas ao repasse a empresas domésticas (HERMANN, 2005: p. 78).

Ademais, conforme antes destacado, o fato de a ditadura militar ser alinhada ideologicamente com os Estados Unidos no contexto da Guerra Fria, também provavelmente facilitou o acesso ao crédito externo. Por exemplo, conforme destaca Lara Resende (1982), "o Brasil foi, durante o período 1964-67, o quarto maior receptor mundial de ajuda da AID" (LARA RESENDE, 1982, p. 782-783 apud BASTIAN, 2013: 163). ${ }^{14}$

14 A AID é a sigla para a United States Agency for International Development, agência do governo 
Por fim, a própria retomada de fortes taxas de crescimento a partir do final dos anos 1960 pode também ter estimulado o aporte de investimentos no Brasil. ${ }^{15}$

Diante deste contexto, como o ajustamento não se deu pelo lado do endividamento, o processo tem necessariamente que ter ocorrido pelo lado das exportações. Neste sentido, a análise dos dados mostra que, de fato, houve uma forte expansão das exportações na segunda metade dos anos 1960 e início dos anos 1970. As exportações de bens e serviços cresceram quase $240 \%$ entre $1962-72$, registrando uma taxa média de crescimento anual de $10,83 \%$ no período em questão, taxa muito superior aos $7,8 \%$ que seriam necessários para fazer a economia brasileira - diante das condições do começo de 1963 - convergir para a zona de segurança proposta por Simonsen \& Cysne (1989) em sua regra de bolso. Em particular, cabe destacar que as exportações brasileiras de bens e serviços passaram por um verdadeiro boom entre 1968-72, registrando crescimento de $112,68 \%$, sendo que a taxa média de crescimento anual neste período foi de $19,77 \%$.

O crescimento das exportações foi acompanhado também por mudanças no perfil da pauta exportadora entre 1962 e 1972, a qual pode ser observada a partir dos dados da Commodity Trade Statistics Database (Comtrade) das Nações Unidas na Tabela 2. Entre outras coisas, as exportações de alimentos e animais vivos que representavam $65,2 \%$ do total exportado em 1962 passaram a representar pouco mais de 55\% em 1972, movimento acompanhado, no mesmo período, pelo segmento matérias brutas não comestíveis, exceto combustíveis com queda de participação de $26,3 \%$ para $20 \%$. Estes dois itens continuaram sendo os mais importantes da pauta exportadora brasileira, mas o seu peso total caiu de 91,5\% em 1962 para 75\% em 1972. Em contrapartida, houve aumento da participação relativa dos produtos manufaturados classificados segundo material de 0,8\% em 1962 para 9\% em 1972, bem como aumento do peso das exportações de maquinaria e equipamentos de transporte de 1\% em 1962 para 5,4\% em 1972 e também do segmento artigos manufaturados diversos que aumentou a sua participação de 0,1\% em 1962 para 2,9\% em 1972. Os resultados mostram que, neste processo de forte crescimento das exportações brasileiras ocorrido en-

norte-americano fundada em 1961 e voltada, segundo sua missão, para ajuda ao combate à pobreza e promoção de sociedades democráticas.

${ }^{15}$ Segundo dados do Banco Central, o investimento direto estrangeiro no Brasil se elevou de US\$ 87 milhões em 1964 para US\$ 154 milhões em 1965 e chegou a US\$ 459,9 milhões em 1972. 
tre 1962 e 1972, houve claramente uma maior diversificação da pauta exportadora.

Tabela 2 - Composição das Exportações Brasileiras (\% total)

\begin{tabular}{|c|c|c|c|c|c|c|c|c|c|c|c|}
\hline & 1962 & 1963 & 1964 & 1965 & 1966 & 1967 & 1968 & 1969 & 1970 & 1971 & 1972 \\
\hline Alimentos e animais vivos & 65,2 & 68,8 & 64,4 & 61,9 & 64,4 & 62,4 & 64,5 & 59,1 & 58,0 & 54,7 & 55,0 \\
\hline Bebidas e tabaco & 2,0 & 1,7 & 2,1 & 1,7 & 1,3 & 1,3 & 1,1 & 1,2 & 1,3 & 1,4 & 1,3 \\
\hline $\begin{array}{l}\text { Matérias primas não comestíveis, } \\
\text { exceto combustíveis }\end{array}$ & 26,3 & 23,0 & 24,9 & 25,0 & 24,6 & 23,5 & 22,9 & 26,1 & 23,3 & 22,0 & 20,0 \\
\hline $\begin{array}{l}\text { Combustíveis minerais, lubrifi- } \\
\text { cantes e materiais relacionados }\end{array}$ & 0,6 & 0,7 & 0,2 & 0,0 & 0,0 & 0,1 & 0,0 & 0,1 & 0,6 & 0,8 & 1,0 \\
\hline $\begin{array}{l}\text { Óleos e gorduras animais e } \\
\text { vegetais }\end{array}$ & 2,7 & 2,6 & 2,8 & 2,9 & 2,2 & 2,2 & 2,8 & 2,7 & 2,5 & 2,7 & 2,8 \\
\hline Produtos químicos & 1,2 & 1,2 & 1,2 & 0,9 & 1,5 & 1,8 & 1,4 & 1,4 & 1,4 & 1,8 & 1,6 \\
\hline $\begin{array}{l}\text { Produtos manufaturados } \\
\text { classificados segundo material }\end{array}$ & 0,8 & 0,9 & 2,7 & 4,9 & 3,5 & 5,2 & 4,3 & 5,4 & 7,7 & 7,0 & 9,0 \\
\hline $\begin{array}{l}\text { Maquinaria e equipamentos } \\
\text { de transporte }\end{array}$ & 1,0 & 0,8 & 1,3 & 1,8 & 1,9 & 2,6 & 2,2 & 2,6 & 3,5 & 4,6 & 5,4 \\
\hline Artigos manufaturados diversos & 0,1 & 0,1 & 0,1 & 0,2 & 0,2 & 0,3 & 0,2 & 0,4 & 0,8 & 2,0 & 2,9 \\
\hline $\begin{array}{l}\text { Mercadorias e operações } \\
\text { não classificadas nas demais } \\
\text { categorias }\end{array}$ & 0,2 & 0,2 & 0,3 & 0,7 & 0,3 & 0,6 & 0,6 & 0,9 & 0,9 & 3,1 & 0,9 \\
\hline
\end{tabular}

Fonte: Comtrade/ Nações Unidas.

A significativa expansão das exportações brasileiras no período 196372 foi, ao menos em parte, resultado de políticas econômicas adotadas durante a ditadura militar. Já no governo Castello Branco (1964-67), houve um esforço de reverter a negligência em relação às exportações que prevaleceu em períodos anteriores. ${ }^{16}$ Neste sentido, afirmou-se no Programa de Ação Econômica de Governo (PAEG) de 1964 que "será a alternativa da exportação que deverá concentrar os esforços de fortalecimento da capacidade de importar" (PAEG, 1964: p. 130). Com isso, o plano anunciou uma série de políticas voltadas para o estímulo das exportações e o período 1964-68 foi caracterizado pela "retirada dos gravames e entraves administrativos que pesavam sobre a atividade" (DOELLINGER et al., 1974:44). As principais medidas contidas no plano estão listadas abaixo:

$\overline{{ }^{16}}$ Na realidade, o Plano Trienal de 1962 já chamava a atenção para a importância do estímulo às exportações, mas, conforme comentado anteriormente, o Plano Trienal foi abandonado precocemente. 
1. "Manutenção de taxas cambiais realísticas, pois o atraso cambial vinha prejudicando as exportações; ${ }^{17}$

2. Racionalização do processo burocrático, como, por exemplo, extinção de documentos desnecessários;

3. Isenção de ônus fiscais sobre a exportação;

4. Simplificação do processo de drawback;

5. Financiamento à exportação e à produção de manufaturas exportáveis, com especial ênfase ao crédito à exportação fornecido pelo CACEX;

6. Instituição de um sistema de seguro de crédito para exportação contra riscos políticos e comerciais;

7. Expansão das linhas diretas de navegação de marítima entre o Brasil e os demais países latino-americanos" (PAEG, 1964: 131-133).

O período 1968-73 seria marcado pela intensificação desta estratégia de estímulo das exportações. De fato, a partir de 1969, surgiu um sistema de isenções tributárias, subsídios fiscais e financiamentos a taxas subsidiadas que "não só proporcionou reduções substanciais nos custos de produção, como também permitiu apreciável margem de lucro nas vendas ao exterior" (DOELLINGER et al., 1974: 43). Dentre as medidas havia, por exemplo, as de abono do IPI e do ICM para empresas industriais que exportassem: os impostos iam sendo abonados quanto maior fosse o volume exportado, podendo as empresas até se tornarem credoras do governo ${ }^{18}$ (DOELLINGER et al., 1974: 21-22). Estas medidas de comércio exterior seriam reforçadas pela política de minidesvalorizações cambiais que passou a ser implantada a partir de agosto de 1968. Nesta política, o intervalo entre as desvalorizações era de três a dez dias, de maneira que, ao impedir a taxa de câmbio real de se apreciar, protegia-se a receita das exportações (ALMEIDA; BACHA, 1999:10). Desta forma, o Brasil passou a apresentar naquele momen-

${ }^{17} \mathrm{Na}$ prática, as exportações somente seriam realmente alavancadas a partir de 1968, quando entrou em vigor o regime de minidesvalorizações cambiais.

${ }^{18}$ A medida de isenção do IPI por volume exportado foi colocada em prática em 1969. A inclusão do ICM ao benefício deu-se em janeiro de 1970, a partir de convênio do governo federal com os estados (DOELLINGER et al., 1974: p. 21). 
to políticas cambial e de comércio exterior francamente favoráveis ao crescimento das exportações.

Todavia, a forte expansão das exportações não pode ser creditada inteiramente às políticas econômicas implementadas no período. Há que se destacar que a conjuntura internacional foi francamente favorável. Entre 1967 e 1973, o comércio mundial expandiu-se 18\% ao ano (MALAN, 1981: 150; 152). Neste contexto, cabe destacar no caso brasileiro que "como os preços de exportação cresciam mais do que os de importação (uma média de 9,4\% ao ano em oposição a 6,2\% para preços de importação), os termos de troca aumentaram cerca de 20\% de 1967 a 1973" (MALAN, 1981:154). Assim, reverteu-se a tendência de deterioração dos termos de troca prevalecente no final dos anos 1950 e início dos 1960. Mais do que isso, esta conjuntura internacional criou um cenário muito favorável para a expansão das exportações brasileiras. Assim, em síntese, a combinação de um cenário externo favorável com políticas econômicas de estímulo às exportações permitiu a forte expansão das exportações de bens e serviços observada entre 1962 e 1972, o que, por sua vez, tornou possível a redução da vulnerabilidade externa (a partir do indicador utilizado), mesmo em um contexto de aumento do montante da dívida externa. ${ }^{19}$

Não obstante, é preciso fazer uma série de qualificações a este processo de ajustamento externo ocorrido entre 1962-72. A primeira está ligada às características do indicador passivo externo líquido sobre exportações de bens e serviços. No caso, a questão é que o indicador leva em conta as exportações, mas não as exportações líquidas. Se o país está aumentando muito as suas exportações de bens e serviços, mas as importações de bens e serviços estão crescendo mais ainda (déficit na balança comercial), o país está, na verdade, perdendo divisas, e não ganhando divisas para honrar seus compromissos externos. Os próprios Simonsen e Cysne (1989) reconhecem esta limitação ao comentar que "a regra [de bolso] é bastante tosca, pois o que interessa aos capitalistas externos é que o país possa, quando necessário, transformar-se de devedor jovem em devedor maduro, para tanto acumulando um saldo comer-

\footnotetext{
${ }^{19}$ Na visão de Fishlow (1976), a forte expansão das exportações foi o que mais distinguiu a experiência brasileira da segunda metade dos 1960 e primeira metade dos 1970 do restante da experiência do país no pós-Segunda Guerra Mundial. Segundo ele, "foi a primeira vez em mais de meio século que o rápido crescimento das exportações se tornou peça chave na estratégia de desenvolvimento" (FISHLOW, 1976:72).
} 
cial ... que exceda a renda líquida enviada ao exterior..." (SIMONSEN e CYSNE, 1989: 74). ${ }^{20}$

Neste contexto, o Gráfico 3 compara as exportações de bens e serviços com as exportações líquidas de bens e serviços (saldo da balança comercial) no período 1963-72 e mostra que, do ponto de vista das exportações líquidas, o quadro externo não é tão favorável: excetuando o triênio 1964-66, o país registrou déficits na balança comercial durante todo o período. Mais do que isso, o déficit comercial se agravou no final dos anos 1960 e começo dos anos 1970, apesar do forte crescimento das exportações neste período.

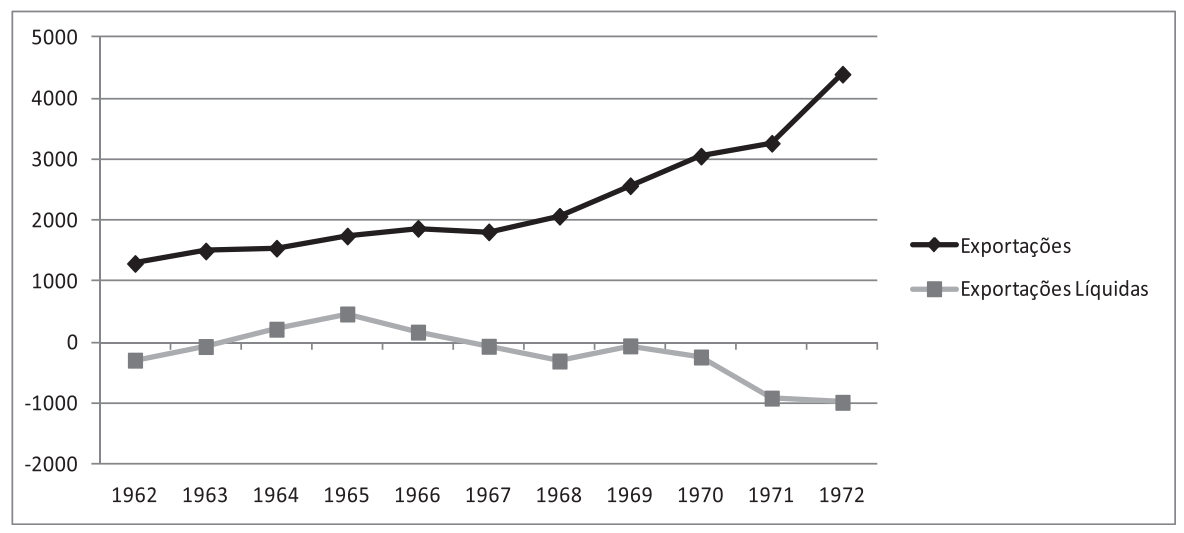

Gráfico 3 - Exportações e Exportações Líquidas (US\$ milhões)

Fonte: Banco Central do Brasil.

Uma importante variável explicativa deste processo é o comportamento das importações associado ao ciclo econômico, posto que as importações apresentavam, nesta época, uma elasticidade em relação ao produto muito superior a 1 (FISHLOW, 1976:38-39). Durante a estagnação da economia brasileira em 1963 (crescimento de 0,6\%) e da lenta recuperação nos dois primeiros anos da ditadura militar (crescimento médio de 2,9\%), as importações sofreram uma queda de 19,38\% entre 1962 e 1965 contra um crescimento de $34,77 \%$ das exportações em igual período. Neste contexto, é interessante notar que, com a renegociação

${ }^{20} \mathrm{Na}$ tipificação proposta pelo autor, devedor jovem é o país com as seguintes características: $\mathrm{H}<0, \mathrm{D}>0$ e $\Delta \mathrm{D}>0$. Por sua vez, o devedor maduro tem as seguintes características: $\mathrm{H}>0$, $\mathrm{D}>0$ e $\Delta \mathrm{D}<0$ (SIMONSEN e CYSNE, 1989, p.72). Renda líquida enviada ao exterior equivale a um déficit na balança de rendas. 
da dívida externa em 1964-65 e o crescimento das exportações líquidas na mesma época, o governo militar conseguiu promover um ajuste nas contas externas já no período 1964-66: em 1966, o indicador passivo externo líquido sobre exportações chegou a 2,199. Contudo, com as altíssimas taxas de crescimento econômico registradas a partir do final da década de 1960 (crescimento médio de 10,6\% entre 1968-72), as importações aumentaram 186,79\% entre 1967 e 1972, superando largamente a taxa de crescimento de $142,78 \%$ das exportações no mesmo período. ${ }^{21}$ Os déficits comerciais reapareceram e, diante do crescente déficit na balança de rendas, ${ }^{22}$ os déficits em conta corrente aprofundaram-se a partir do final dos anos 1960 (Gráfico 4), aumentando a necessidade de financiamento externo. $\mathrm{O}$ indicador déficit em conta corrente sobre exportações (de bens e serviços) fechou o ano de 1972 em - 0,38 contra - 0,35 registrado ao fim de 1962, ou seja, o quadro de solvência externa, medido por esse indicador, apontava para uma ligeira piora em 1972 em relação ao começo do período analisado. Assim, apesar de o indicador de solvência externa proposto por Simonsen e Cysne (1989) estar próximo a 2 em 1972,23 o quadro externo não era tão benigno.

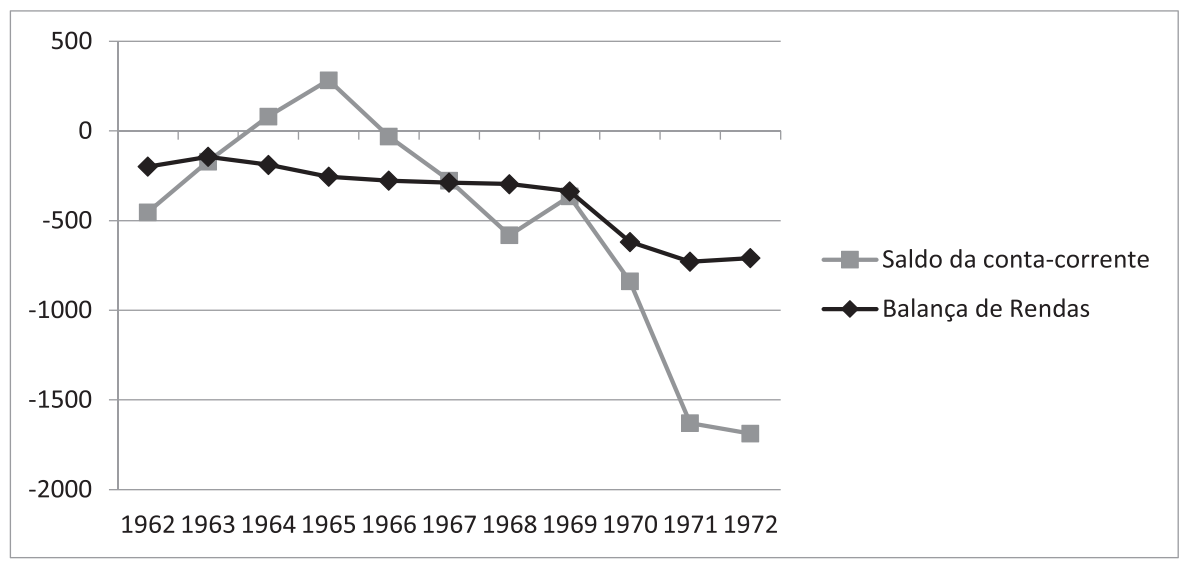

Gráfico 4 - Balança de Rendas e Saldo da conta-corrente (US\$ milhões)

Fonte: Banco Central do Brasil.

\footnotetext{
${ }^{21}$ Contas a partir de dados do Banco Central.

${ }^{22} \mathrm{O}$ aumento do déficit de rendas foi provavelmente uma resultante do próprio aumento do endividamento externo a partir do final dos anos 1960. O aumento no passivo externo tende a provocar maiores déficits na balança de rendas. Este é um aspecto importante, pois um passivo externo maior acaba por causar uma realimentação no processo de endividamento externo.

${ }^{23} \mathrm{O}$ valor do indicador para 1972 era 2,158.
} 
Outra ressalva importante ao processo de ajustamento ocorrido entre 1962 e 1972 é apresentada por Cruz (1984). No caso, o autor relativizou exatamente a ideia de que o período do milagre econômico foi uma fase em que o endividamento externo teve importância grande nas altas taxas de crescimento. Para ele, a ampliação da dívida não ocorreu especificamente como uma resposta à necessidade de superar constrangimentos do setor externo em função do forte crescimento verificado nesta fase de milagre econômico, uma vez que os recursos necessários para cobrir os déficits na balança comercial e na balança de serviços eram bem menores do que o superávit verificado na conta [financeira e] ${ }^{24}$ de capital (CRUZ, 1984: p. 17-18). ${ }^{25}$ Ademais, conforme destacou Wells (1973), o Brasil estava assumindo riscos, uma vez que, já nesta fase do milagre econômico, o país vinha acumulando dívida externa a taxas de juros flexíveis, o que o deixava exposto a reversões na economia internacional que estavam fora de seu controle (WELLS, 1973: 20; 22). Assim, o endividamento ocorrido no período foi - ao menos parcialmente - desnecessário e, além disso, se deu de uma maneira que fragilizava externamente a economia para o médio e longo prazos.

Por fim, é preciso lembrar que o final da década de 1960 e o começo dos anos 1970 foram extremamente particulares do ponto de vista da economia internacional, tendo em vista a forte expansão do comércio internacional e dos fluxos internacionais de capitais e a difusão de ambos para a periferia da economia mundial (MALAN, 1981: 151-152). Neste contexto, o processo de expansão das exportações e a possibilidade de reduzir o indicador passivo externo líquido sobre as exportações de bens e serviços - mesmo em face de um aumento do endividamento externo - deveram-se, ao menos em parte, a estas condições peculiares e muito favoráveis do período em questão. Com a mudança do cenário externo a partir do Primeiro Choque do Petróleo em 1973, a possibilidade de continuar se endividando e compensar esta maior dívida com expansão das exportações ficou - ao menos em parte - comprometida.

\footnotetext{
${ }^{24}$ O termo utilizado por Cruz (1984) é conta de capital. O termo conta financeira e de capital é posterior ao livro.

25 "As contratações líquidas de empréstimos e financiamentos tiveram como contrapartida principal a formação de reservas internacionais" (CRUZ, 1984: 17).
} 


\section{Conclusões}

O artigo procurou discutir o grau de sustentabilidade do endividamento externo brasileiro quando do início do governo presidencialista de João Goulart. Neste contexto, utilizou-se um modelo proposto por Mário Henrique Simonsen e Rubens Penha Cysne, que permitia fazer esta avaliação em função do comportamento ao longo do período 1963-72 da variável passivo externo líquido sobre exportações de bens e serviços.

A análise a partir do modelo permitiu observar que o Brasil encontrava-se, naquele momento, em uma situação de grande vulnerabilidade externa, uma vez que, mantidas as condições então vigentes, o indicador passivo externo líquido sobre exportações de bens e serviços apresentaria comportamento explosivo nos anos subsequentes. Esse quadro de vulnerabilidade externa foi confirmado também pelo indicador de liquidez externa e pelo indicador alternativo de solvência externa. No entanto, por outro lado, observou-se que - do ponto de vista do indicador passivo externo líquido sobre exportações de bens e serviços - este processo poderia ser detido através de políticas de estímulo às exportações.

A avaliação dos dados do período 1962-72 mostrou que, na prática, a economia moveu-se na direção de uma menor vulnerabilidade externa, uma vez que o indicador de solvência aproximou-se dos patamares de segurança sugeridos pela regra de bolso de Simonsen e Cysne (1989). Além disso, o indicador dívida externa líquida sobre exportações de bens e serviços também se reduziu significativamente no período. Este processo de ajustamento externa deveu-se às políticas de estímulo às exportações feitas pelos primeiros governos da ditadura militar e por uma conjuntura internacional extremamente vantajosa para a economia brasileira.

Todavia, fizeram-se algumas ressalvas ao processo de ajustamento externo da economia brasileira no período em questão. Por um lado, mostrou-se, por exemplo, que o forte crescimento das exportações foi acompanhado - a partir do final dos anos 1960 - por uma expansão ainda mais forte das importações que passou a provocar déficits na balança comercial. Nesse contexto, por exemplo, o indicador déficit em conta corrente sobre exportações de bens e serviços registrava em 1972 um valor ligeiramente pior que o de 1962. Além disso, chamou atenção o fato de que houve um aumento (em parte desnecessário) do endividamento externo no período, e para o fato de este endividamento estar 
associado a taxas de juros flexíveis, sujeitas a variações dependendo do comportamento da economia mundial. Por fim, a possibilidade de reduzir os riscos de insolvência ao mesmo tempo em que se aumentava o endividamento foi resultado do contexto internacional favorável prevalecente no final dos 1960 e início dos 1970. Com o choque do petróleo de 1973, as condições na economia mundial foram modificadas, o que criou restrições para a continuidade desta estratégia.

\section{Referências}

ALMEIDA, C. O.; Bacha, C. J. C. Evolução da política cambial e da taxa de câmbio no Brasil, 1961-97. Pesquisa \& Debate, volume 10(2):5-29, 1999. Disponível em: <http://revistas.pucsp.br/index.php/ rpe/article/viewFile/11909/8624>.

BASTIAN, E.F. A Sustentabilidade do Endividamento Externo Brasileiro Pós-Desvalorização: Análise e Projeções. Monografia de Bacharelado em Ciências Econômicas (não publicada). Instituto de Economia, Universidade Federal do Rio de Janeiro, 2001.

BASTIAN, E.F. O Paeg e o Plano Trienal: uma análise comparativa de suas políticas de estabilização de curto prazo. Estudos Econômicos. São Paulo, volume 43(1):139-166, jan.-mar. 2013. Disponível em: $<$ http://www.scielo.br/pdf/ee/v43n1/a06v43n1.pdf $>$.

BONELLI, R.; Malan, P. S. Os limites do possível; notas sobre o balanço de pagamentos e indústria nos anos 70. Pesquisa e Planejamento Econômico. Rio de Janeiro, volume 6(2):353-406, ago. 1976. Disponível em: <http://www.ppe.ipea.gov.br/index.php/ppe/article/viewFile/626/568>.

CARNEIRO, D. D.. A Sustentabilidade dos Déficits Externos. RJ: Departamento de Economia PUC -Rio, 1997. 19p. (Texto para Discussão, n. 384). Disponível em: <http://www.econ.puc-rio.br/pdf/td384.pdf>.

CHIANG, A. Matemática para Economistas. São Paulo: Editora da Universidade de São Paulo, 1982.

CRUZ, P.D. Dívida Externa e Política Econômica. São Paulo: Brasiliense, 1984.

DOELlinger, C.V.; Faria, H. B.C.; Cavalcanti, L. C. A Política Brasileira de Comércio Exterior e Seus Efeitos: 1967-73. Rio de Janeiro: IPEA/INPES, 1974.

FISHLOW, A. Foreign Trade Regimes and Economic Development: Brazil. Mimeografado, 1976.

FONSECA, P.C.D. Legitimidade e Credibilidade: Impasses da Política Econômica do Governo Goulart. Estudos Econômicos, v.34(5), 2004. Disponível em: <http://www.scielo.br/pdf/ee/v34n3/v34n3a07>.

GIAMBIAGI, F.; Reis, E.; Cavalcanti, M. A.; Castro, A.S. O Balanço de Pagamentos e o Passivo Externo do Brasil: Perspectivas de Médio Prazo. Pesquisa e Planejamento Econômico, Rio de Janeiro, volume 28(3), 1998. Disponível em: http://ppe.ipea.gov.br/index.php/ppe/article/viewFile/701/641>.

GOULD, E.R. Money Talks: the international monetary fund, conditionality and supplementary financiers. Stanford: Stanford University Press, 2006.

HERMANN, J. Reformas, Endividamento Externo e o "Milagre" Econômico (1964-73). In: Giambiagi, F.; Villela, A.; Castro, L.B.; Hermann, J.(org.). Economia Brasileira Contemporânea (1945-2004). Rio de Janeiro: Campus, 2005.

LARA, F. Solvência e liquidez externas: aspectos teóricos, contábeis e a definição de indicadores sintéticos para análise de conjuntura. Fundação de Economia e Estatística Siegfried Emanuel Heuser (FEE). Textos para Discussão FEE n.101, 2012. 
LARA RESENDE, A. A Política Brasileira de Estabilização 1963/68. Pesquisa e Planejamento Econômico, vol. 12, n.3, p.757-806, 1982. Disponível em: <http://ppe.ipea.gov.br/index.php/ppe/article/ viewFile/395/336>.

LOUREIRO, F.P. A Última Chance"; o governo Kennedy e o Plano Trienal. Anais do IX Congresso Brasileiro de História Econômica e 10a Conferência Internacional de História de Empresas, Curitiba, 07-09 de setembro, 2011.

MALAN, P. S. Política Econômica e Teorias de Balanço de Pagamentos: relações internacionais do Brasil no periodo 1946-1979. Tese (não publicada) apresentada à Faculdade de Economia e Administração da Universidade Federal do Rio de Janeiro para Concurso de Professor Titular, 1981.

MALAN, P.S. Relações Econômicas Internacionais do Brasil (1945-1964). In: FAUSTO, Boris (dir.). História Geral da Civilização Brasileira: Tomo III - O Brasil Republicano - Economia e Cultura (1930-1964). São Paulo: DIFEL, 1984.

MEDEIROS, C.A.; Serrano, F. Inserção externa, exportações e crescimento no Brasil. In: FIORI, J.L.; MEDEIROS, C. (org.). Polarização Mundial e Crescimento. Petrópolis: Editora Vozes, 2001.

MELO, H.; Bastos, C.P.; Araújo, V.L. A Política Macroeconômica e o Reformismo Social: impasses de um governo sitiado. In: FERREIRA, Maria de Moraes (coor.). João Goulart: entre a História e memória. Rio de Janeiro: FGV, 2008.

PAEG - Programa de Ação Econômica do Governo 1964-1966. Documentos EPEA - nº 1, Rio de Janeiro, 1964.

PIRES DE SOUZA, F. E. A redução da vulnerabilidade externa: dilemas, custos e alternativas In: Dias Leite, A.; Velloso, J.P.R. (coordenadores). O novo governo e os desafios do desenvolvimento. Rio de Janeiro: J. Olympio, 2002.

PLANO TRIENAL DE DESENVOLVIMENTO ECONÔMICO E SOCIAL 1963-65 (Síntese). Presidência da República, 1962.

RIBEIRO, R.A. A Aliança para o Progresso e as Relações Brasil- Estados Unidos. Tese de Doutorado, Departamento de Ciência Política do Instituto de Filosofia e Ciências Humanas - Universidade Estadual de Campinas (Unicamp), 2006. Disponível em: <http://www.bibliotecadigital.unicamp.br/ document/?code $=$ vtls000410430>.

SIMONSEN, M.H.; CYSNE, R. P. Macroeconomia, Rio de Janeiro: Ao Livro Técnico S.A, 1989.

TERRA, M.C. Finanças Internacionais: Macroeconomia Aberta. Rio de Janeiro: Elsevier, 2014.

WELLS, J. Euro-dólares, dívida externa e o milagre brasileiro. Estudos Cebrap, n.6, p.6-34, 1973. Disponível em: $<$ http://www.cebrap.org.br/v2/files/upload/biblioteca_virtual/euro_dolares_divida_externa.pdf $>$. 


\section{Apêndice $^{26}$}

A discussão de Simonsen e Cysne (1989; 2007) começa com a equação da dívida, a qual descreve a evolução ao longo do tempo do passivo externo líquido. A equação está baseada no fato de a variação do passivo externo líquido, em um dado período de tempo, poder ser medida - de forma aproximada - pelo déficit em conta corrente verificado no mesmo. Supondo tempo contínuo e decompondo esse déficit em renda líquida enviada ao exterior e superávit (déficit) da balança comercial, ${ }^{27}$ obtém-se então a equação da dívida (SIMONSEN; CYSNE, 1989: 71).

$$
\mathrm{dD} / \mathrm{dt}=\mathrm{iD}-\mathrm{H}
$$

$\mathrm{dD} / \mathrm{dt}=$ derivada em relação ao tempo do passivo externo líquido

$\mathrm{i}=$ taxa de remuneração do passivo externo líquido

$\mathrm{H}=$ superávit da balança comercial

A parcela iD corresponde ao déficit na balança de rendas. Por simplificação, são excluídas as rendas do trabalho e aquilo que na metodologia vigente em 1989 se chamava de transferências unilaterais. ${ }^{28}$ Dessa forma, $i$ representa uma taxa média de remuneração dos capitais externos. A transferência líquida de recursos corresponde às exportações líquidas de bens e serviços, de forma que o passivo externo líquido (D) decresce à medida que $H$ aumenta ceteris paribus.

A partir de alguma álgebra, pode-se chegar à outra equação (Equação 2) que mede a sustentabilidade do endividamento externo, a qual depende da relação entre o passivo externo líquido e as exportações de bens e serviços fatores. Neste contexto, a Equação 2 está medindo como a capacidade de pagamento externo de um país varia ao longo do tempo.

$$
\mathrm{dz} / \mathrm{dt}=(\mathrm{i}-\mathrm{x}) \mathrm{z}-\mathrm{h}
$$

${ }^{26} \mathrm{O}$ apêndice se baseia em Bastian (2001).

${ }^{27}$ Conforme explicado anteriormente, no modelo original de Simonsen e Cysne (1989), o termo $H$ designava a transferência líquida de recursos e $(-H)$ o hiato de recursos.

${ }^{28}$ As transferências unilaterais englobavam "os pagamentos e recebimentos sem contrapartida de serviços, doações, remessas de imigrantes, reparações de guerra...” (SIMONSEN e CYSNE, 1989:62). 
$\mathrm{z}=\mathrm{D} / \mathrm{X}=$ passivo externo líquido sobre exportações de bens e serviços

$\mathrm{dz} / \mathrm{dt}=$ derivada em relação ao tempo do parâmetro $z$

$\mathrm{x}=$ taxa instantânea de crescimento das exportações de bens e serviços

$\mathrm{h}=\mathrm{H} / \mathrm{X}=$ superávit da balança comercial sobre exportações de bens e serviços

A resolução desta equação diferencial linear não homogênea é bastante simples. A solução de uma equação dessa natureza é expressa através da soma de dois termos: a função complementar $\left(\mathrm{z}_{\mathrm{c}}\right)$ e a integral particular $\left(\mathrm{z}_{\mathrm{p}}\right)$. A função complementar corresponde à solução de uma equação homogênea (quando $h=0$ ) e a integral particular fornece qualquer solução particular da equação não homogênea em questão (CHIANG, 1982: p. 409).

A função complementar pode ser calculada através do método de separação de variáveis:

Supondo: $(\mathrm{i}-\mathrm{x})=\mathrm{a}$, tem-se que:

$$
\begin{gathered}
\mathrm{dz} / \mathrm{dt}-\mathrm{az}=0 \\
\mathrm{dz} / \mathrm{dt}=\mathrm{az} \\
\mathrm{dz} / \mathrm{z}=\mathrm{adt} \\
\ln \mathrm{z}=\mathrm{at}+\mathrm{C} \\
\mathrm{e}^{\ln \mathrm{z}}=\mathrm{e}^{\mathrm{at}+\mathrm{C}} \\
\mathrm{z}=\mathrm{Be}^{\mathrm{at}} \\
\mathrm{z}_{\mathrm{c}}=\mathrm{Be}^{(\mathrm{i}-\mathrm{x}) \mathrm{t}}
\end{gathered}
$$

A integral particular é uma constante:

$$
\begin{aligned}
& \mathrm{z}_{\mathrm{p}}=\mathrm{h} / \mathrm{a} \\
& \mathrm{z}_{\mathrm{p}}=\mathrm{h} /(\mathrm{i}-\mathrm{x}) \quad(\text { para } \mathrm{i} \neq \mathrm{x})
\end{aligned}
$$


A constante arbitrária $B$ pode ser descrita por uma condição inicial. Supondo que $z$ assuma o valor $z_{0}$ quando $t=0$, então $B=z_{0}-h /(i-x)$. Dessa forma, a solução da equação diferencial é justamente a equação 1 da página 3:

$$
\mathrm{z}_{(\mathrm{t})}=\left[\mathrm{z}_{0}-\mathrm{h} /(\mathrm{i}-\mathrm{x})\right] \mathrm{e}^{(\mathrm{i}-\mathrm{x}) \mathrm{t}}+\mathrm{h} /(\mathrm{i}-\mathrm{x})
$$

$\mathrm{z}_{0}=$ valor inicial da relação passivo externo líquido sobre exportações

$\mathrm{t}=$ tempo

A solução acima é válida somente para o caso em que $i$ é diferente de $x$. Assim, existe ainda uma segunda solução possível correspondente à situação em que $\mathrm{i}=\mathrm{x}$. Esta solução é obtida via integração e corresponde à equação $\mathrm{z}_{(\mathrm{t})}=\mathrm{z}_{0}$ - ht. Como é muito difícil que os valores de $x$ e $i$ sejam idênticos, só se utiliza, no trabalho, a solução para i diferente de $x$. 